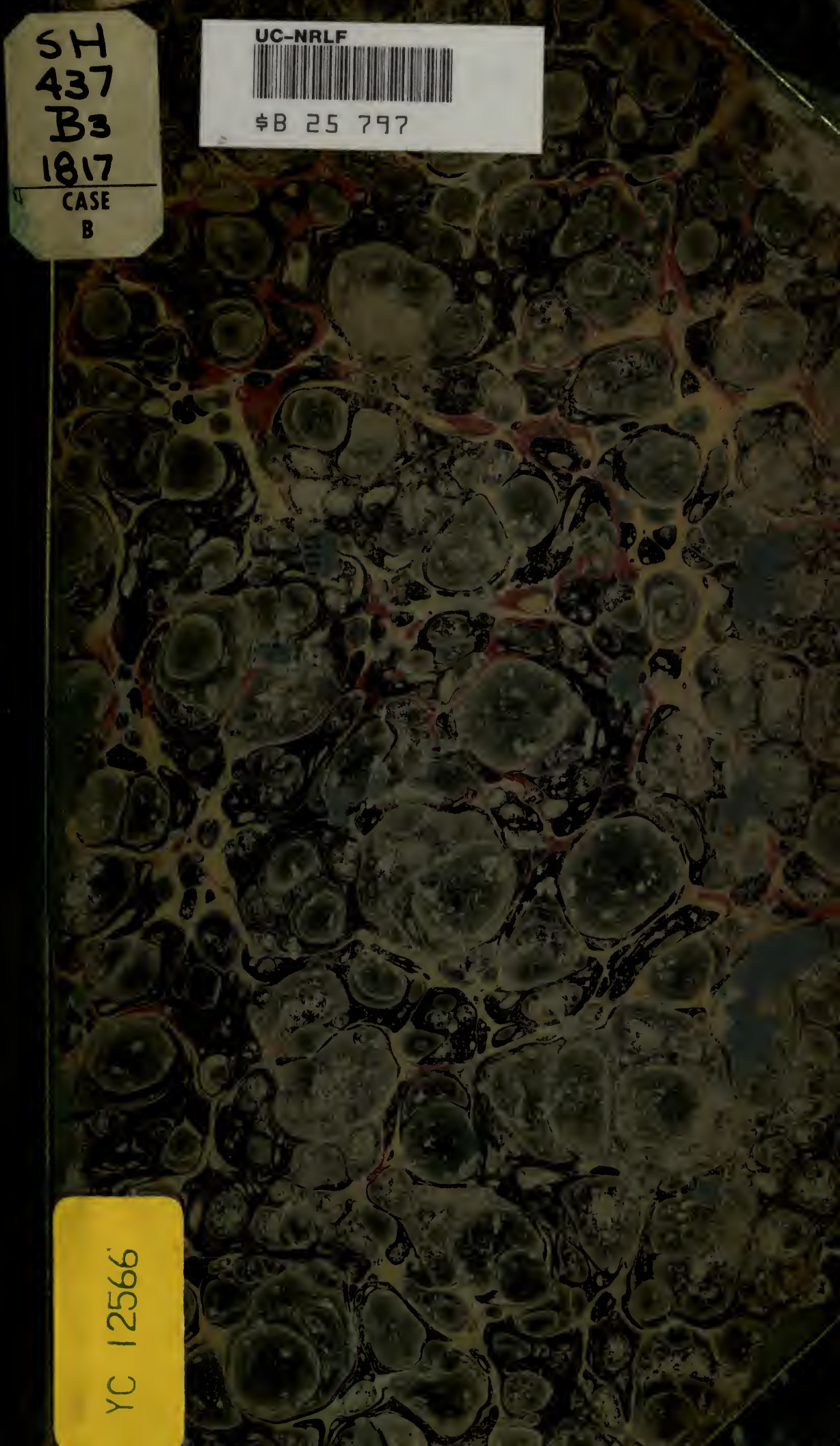



EON/

$$
\text { pen }
$$


Digitized by the Internet Archive in 2007 with funding from Microsoft Corporation 
$E 0^{11} / 6^{10^{\circ}}$

$\mathrm{BS}^{2}$

$(199)$ 
, 
is

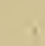





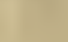

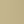




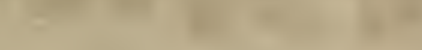

$\sqrt{1}$

$x$
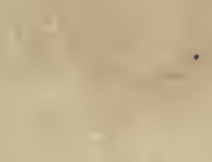

f
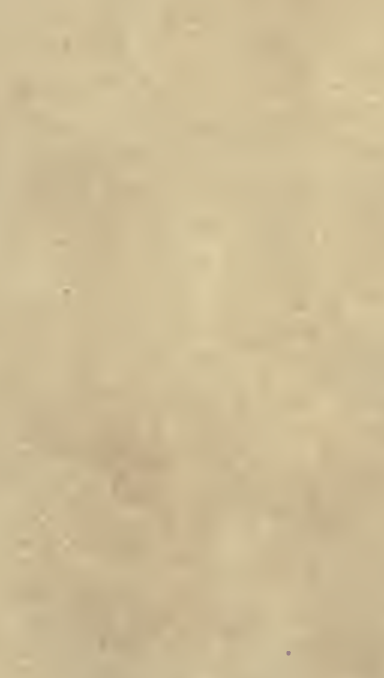

$+2$

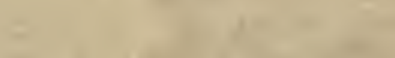





\section{Barker's Art of}

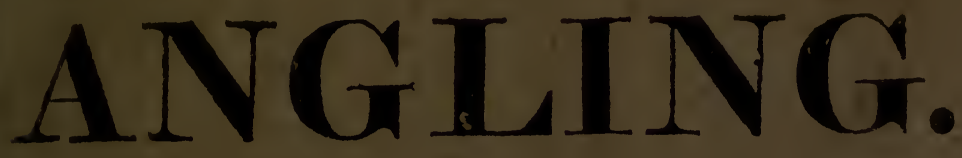

WHEREIN

A re discovered many rare Secrets, very necessary to be knowne

by all that delight in that Recreation.

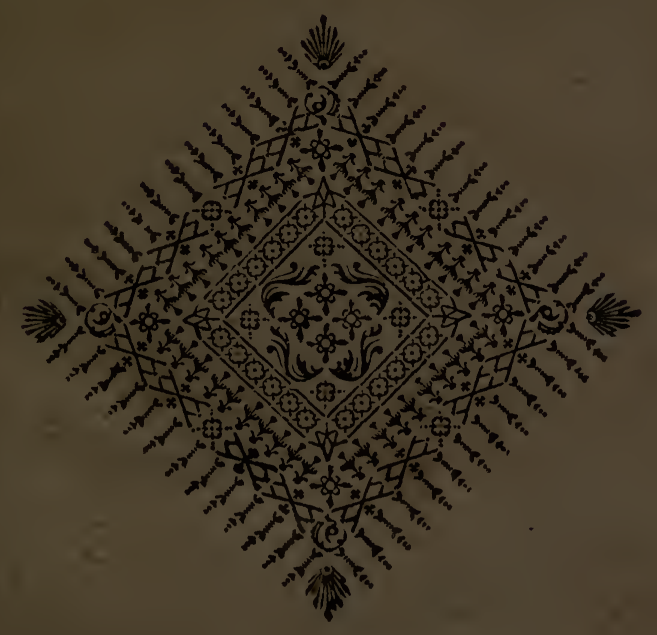

LONDON,

Printed in the Yeare 1653.

Leeds : Reprinted by Inchbold and Gawtress, for Robinson, Son, and Holdsworth, 1817. 


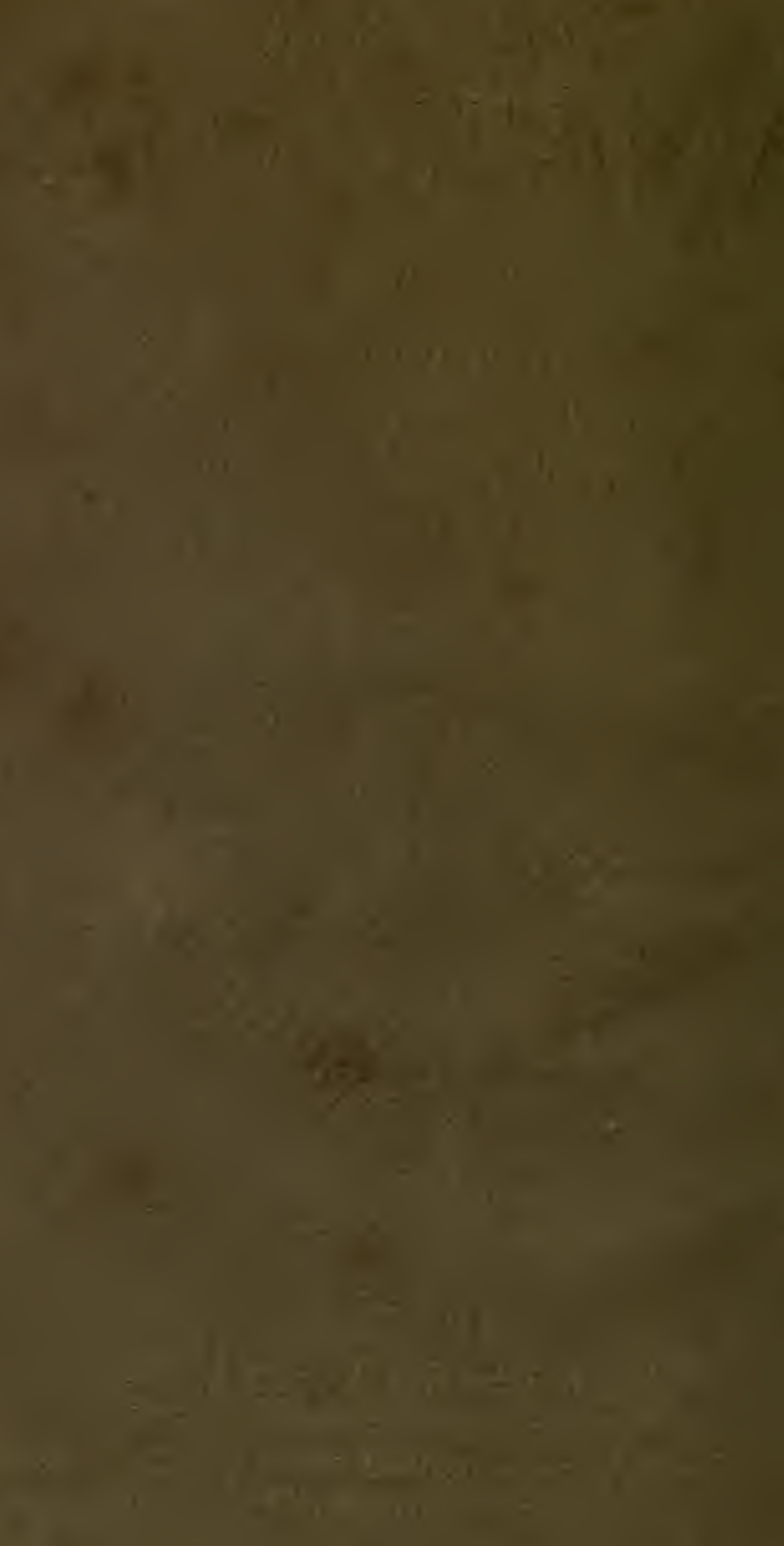




\title{
The Art of
}

\section{ANGLING.}

\author{
WHEREIN
}

Are discovered many rare Secrets, very necessary to be knowne by all that delight in that Recreation.

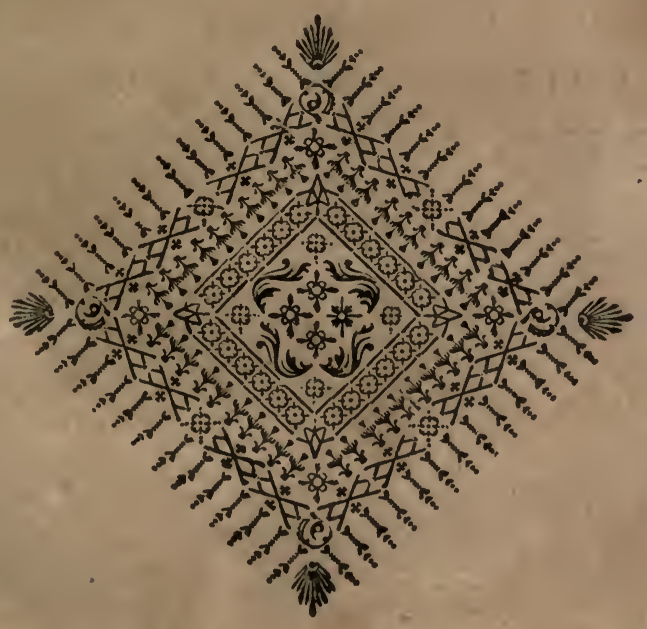

LONDON,

Printed in the Yeare 1653. 


\section{CASE}

i.

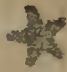

ONLY ONE HUNDRED COPIES PRINTED.

Reprinted by Inchbold and Gaweress, Leed».

1817. 


\section{The Art of Angling.}

\% (t) you. I met with a man, and upon . $R$ our Discourse he fell out with me : this Al o man having a good weapon, having nei-

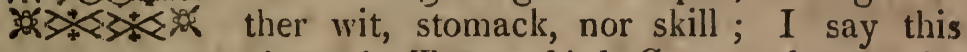
man may come home by Totnam-high-Cross, and cause the Clerk to tole his knell : It is the very like case with the Gentleman Angler that goeth to the River for his pleasure: this Angler luath neither judgment, knowledge, nor experience; he may come home light laden at his pleasure.

A man that goeth to the River for his pleasure, must understand, when he cometh there, to set forth his Tackles. The first thing he must do, is to observe the Sun, the Wind, the Moon, the Starres, and the Wanes of the Air ; to set forth his Tackles according to the times and seasons; to goe for his pleasure, and some profit.

As for example, the Sun proves cloudy; then must he set forth either his ground Bait or Tackles, and of the brightest of his Flies. If the Sun prove bright, then must he put on some of the darkest of his flies. Thus must you goe to work with your Flies, light for darkness, and dark for lightness, with the wind in the South, then that blows the Flie in the Trouts mouth. Though I set down the wind being in the South, if the weather be warm, I am indifferent where the wind standeth, either with ground Bait or Menow, so that I can cast my Bait into the River. The very same observations is for night, as for day : For if the Moon prove cleer, or if the Stars glitter in the skie, there is as ill Angling that night, as if it were at high noon in the midst of Summer, when the Sun shineth at the brightest, wherein there is no hopes of pleasure.

I will begin to Angle for the Trout, with the ground Baits with this quality. 
The first thing you must gaine, must be a neat taper Rod, light before, with a tender hazell top, which is very gentle. If you desire to attain my way of Angling; (for I have Angled these forty years) with a single haire of five lengths, one tied to another for the bottom of my Line, and a Line of three haired links for the uppermost part ; and so you may kill the greatest Trout that swims, with Sea-room.

He that Angles with a Line made of three haired links at the bottom, and more at the top, may kill Fish : but he that Angles with one hair shall kill five Trouts to the others one; for the Trout is very quick sighted; therefore the best way for night or day, is to keep out of the sight. You must Angle alwayes with the point of your Rod downe the stream ; for a Fish hath not the quickness of sight so perfect up the stream, as opposite against him, observing seasonable times ; as for example, we begin to Angle iu March; If it prove cloudie, you may Angle with the ground Baits all day long : but if it prove bright and cleere, you must take the morning and evening, or else you are not like to do any good; so the times must be observed, and truely understood; for when an Angler commeth to the River for his pleasure that doth not understand to set forth his Tackles fit for the time, it is as good keep them in the bag, as set them forth.

I am determined to Angle with the ground Baits and set my Tackles to my Rod, and go to my pleasure : I begin at the uppermost part of the streame, carrying my Line with an upright hand, feeling the Plummet running on the ground some ten inches from the hook, plumming my Line according to the swiftnesse of the stream you Angle in; for one plummet will not serve for all streams ; for the true Angling is that the plummet runneth on the ground.

For the Bait. The red knotted worme is very good where Brandlins are not to be had, but Brandlins are better: now that you may bring these Brandlings fit to Angle with, that they may live long on the hook, which causeth the best sport. When you have gathered your worms out of the dung-hill, you must gaine the greenest Moss you can find, then wash the earth very clean out of it, then provide an earthen pot, so put your Moss into the pot, then put the 
Worms to the Moss into the pot; within two days you shall find your worms so poor, that if you bait some of them on your hook, you shall see that with throwing of them two or three times into the water, they will dye and grow white : now the skill is, when these worms be grown poor, you must feed them up to make them fat and lusty, that they may live long on the hook; that is the chiefest point.

To make them lusty and fat, you must take the yolke of an Egge, some eight or ten spoonfull of the top of new milk, beaten well together in a Porringer, warm it a little, untill you see it curdle; then take it off the fire, and set it to coole ; when it is cold, take a spoonfull and drop it upon your Moss into the pot, every drop about the bignesse of a green l'ea, shifting your Mloss twice in the week in the Summer, and once in the winter: thus doing, you shall feed your wormes fat, and make them lusty, that they will live a long time on the hook ; so you may keep them all the year long. This is my true experience for the ground Baits, for the running Line for the Trout.

The Angling with a Menow, called in some places Pencks for a Trout, is a pleasant sport, and killeth the greatest Fish ; he commeth boldly to the Bait, as if it were a Mastive Dog at a Beare : you may Angle with greater 'Tackles, and stronger, and be no prejudice to you in your Angling: a Line made of three silks and three hairs twisted for the uppermost part of the Line, and two silkes and two haires twisted for the bottone next your hook, with a Swivel nigh the middle of your Line, with an indifferent large hook.

To bait your hook with a Menow, you must put your hook through the lowermost part of his mouth, so draw your hook thorow, then put the hook in at the mouth againe, let the point of the hook come out at the hindmost Fin, then draw your Line, and the Menowes mouth will close, that no water will get into its belly; you must alwayes be Angling with the point of your Rod down the stream, with drawing the Menow up the stream by little and little, iigh the top of the water; the Trout seeing the bait, commeth at it most fiercely, so give a little time before you strike : This is the true way, without Lead; for many times I have had them come at the Lead and forsake the Menow, so he that 
tryeth shall prove it in time : let us go to Angling with a Flie, which is a delightfull sport.

The Rod must be light and tender, if you can fit yourselfe with an Hazell, either of one piece or two set together in the most convenient manner, light and gentle: set your Line to the Rod; for the uppermost part, you may use your owne discretion ; for the lower part, next your Flie, inust be of three or foure haired links. If you can attain to Angle with one haire, you shall have the more rises, and kill more fish ; be sure you doe not over-load yourself with the length of your Line : before you begin to Angle, make a triall, having the winde in your back to see at what length you can cast your Flie, that the Flie light firstinto the water, and no longer; for if any of the Live falleth into the water before the Flie, it is betler unthrowne then throwne; be sure you be casting alwayes downe the stream, with the Wind behinde you, and the Sun before; it is a speciall point to have the Sunne and Moon before you; for the very motion of the Rod drives all the pleasure from you, either by day or night in all your Anglings, both for Wormes and Flies; so there must bee a great care of that.

Let us begin to Angle in March with the Flie : If the weather prove Windie, or Cloudie, there are severall kindes of Palmers that are good for that time.

First, a black Palmer ribbed with silver : the second, a black Palmer with an Orange-tauny body: thirdly, a black Palmer, with the body made all of black : fourthly, a red Palmer ribbed with gold, and a red hackle mixed with Orenge cruel ; these Flies serve all the year long morning and evening, windie and cloudie. Then if the Aire prove bright and cleare, you must imitate the Hauthorn Flie, which is all black and very small, and the smaller the better. In May take the May-flie: imitate that, which is made severall wayes; some make them with a shammy body, ribbed with a black haire: another way made with SandyHogges wooll, ribbed with black silke, and winged with a Mallards feather, according to the fancy of the Angler. There is another called theOak-Flie, which is made of Orange colour Cruell and black, with a browne wing; imitate that: Another Flie, the body made with the strain of a Pea-Cocks 
feather, which is very good in a bright day : The Grassehopper which is green imitate that; the sinaller the Flies be made, and of indifferent small hooks, they are the better; these sorts I have set downe, will serve all the year long, observing the times and seasons : Note, the lightest of your Flies for cloudy and darknesse, and the darkest of your Flies for lightnesse, and the rest for indifferent times; that a mans owne Judgement, with some experience and discretion must guide him : If he mean to kill Fish, he must alter his Flies according to these directions. Now, of late, I have found, that Hogs-wooll, of severall colours, makes good grounds; and the wooll of a red Heyfer makes a good body: And Bears wool makes a good ground; so I now.work much of them, and it procureth very much sport.

The naturall Flie is sure Angling, and will kill great store of Trouts with much pleasure: As for the May-Flie, you shall have them always playing at the River side, especially against Raine. The Oake-Flie is to bee had on the butt of an Oake, or an Asb, from the beginning of May to the end of August: it is a brownish Flie, and stands alwayes with his head towards the root of the tree, very easie to be found: The small black Flie is to be had one evry Hawthorn Bush, after the buds be come forth : Your Grasse-hopper, which is green, is to be had in any Medow of Grasse in June or July: with these Flies, you must Angle with such a Rod as you Angle with the ground Bait; the Line must not be so long as the Rod : with drawing your flie, as you finde convenient in your Angling. When you come to deep waters that stand somewhat still, make your Line some two yards long, or thereabout, and dop your Flie behinde a bush, which Angling I have had good sport at ; we call it doping.

$\Lambda$ Lord lately sent to me at Sun going down, to provide him a good dish of Trouts against the mext morning by. six of the Clock: I went to the door to see how the wains of the Aire were like to prove, and returned answer, that I doubted not but to be provided (God willing) at my time appointed. I went presently to the River, and it proved very dark; I drew out a line of three silkes and three hairs twisted for the uppermost part, and a Line of two silks and two 
hairs twisted for the lowermost part, with a good large hook : I baited my hook with two Lob-worms, the four ends hanging as meet as I could ghesse them in the dark : I fell to Angle ; it proved yery dark, that I had good sport, Angling with the Lob-worms, as I doe with the Flie, at the top of the water; you shall heare the Fish rise at the top of the water; then you must loose a slack Line down to the bottome, as nigh as you can ghesse, then hold a straight Line; feeling the Fish bite, give time, there is no doubt of losing the Fish ; for there is not one among twenty, but doth gorge the Bait: the least stroak you can strike to fasten the hook, makes the fish sure, and then you may take the fish up with your hands: The night began to alter and grew somewhat lighter; I took off the Lob-worms, and set to my Rod a white Palmer Flie, made of a large hook, I had sport for the time, till it grew lighter; then I put on my red Palmer, I had sport for the time untill it grew very light ; then I set on my black Palmer, had good sport, made up my dish of fish, put up my Tackles, and was at iny time appointed for the service. For these three Flies, with the help of the Lob-worms, serve to Angle all the year long, observing the times, as I have shewed in this nights work: a light Flie for darknes, the red Flie in medio, and a dark Flie for lightnesse: This is my experiment for this kind of Angling, which is the surest Angling of all, and killeth the greatest Fish : your Lines may be strong, but must be no longer than the Rod.

To take a Carp either in Pond or River, if you mean to have sport with some profit, you must take a peck of Alegraines, and a good quantity of any bloud, and mix the bloud and graines together, and cast it in the places where you meane to Angle; this feed will gather the scale Fish together, as Carp, Tench, Roach, Dace, and Bream; the next morning be at your sport very early, plum your ground: you may Angle for the Carp with a strong Line; the Bait must be either a red knotted worm, or Paste: there is no doubt of sport.

To take Pearch. The Pearch feeds well, if you light where they be, and bites very free : My opinion is, (with some experience) to bait with Lob-worms, chopt in pieces 


\section{(9)}

over night; so come in the morning betimes, plum your ground, gage your line, bait your hook with a red knotted worme; but I hold a Menowbetter: put the hook in at the back of the Menow, betwixt the fish and the skin, that the Menow may swim up and down alive, being boyed up with a Curk or Quill, that the Menow may have liberty to swimme a foot off the ground: there is no doubt of sport with profit.

I will shew, a little, my opinion of floating for scale fish in the River or Poud: The feed brings the Fish together, as the sheep to the Pen: There is nothing better in all your Anglings, for feed, then Bloud and Grains; I hold it better then Paste: then plumming your ground, Angling with fine 'Tackles, as single haire for halfe the Line next the hook, round and small plumed, according to your float: For the Bait, there is a small red worm, with a yellow tip on his taile, is very good; Brandlins, Gentles, Paste, or Cadice, which we call Cod-bait, they lye in a gravelly husk under stones in the River: these be the speciall Baits for these kinde of Fish.

One of my name was the best Trouler, for a Pike, in this Realme : he laid a wager, that he would take a Pike of four foot long, of Fish, within the space of one Moneth, with his Trouling-Rod; so he Trouled three weeks and odde days, and took many great Pikes, nigh the length, but did not reach the full length, till within the space of three dayes of the time; then he took one, and won the wager. The manner of his Trouling was, with a Hazell Rod of twelve foot long, with a Ring of Wyre in the top of his Rod, for his Line to runne thorow: within two foot of the bottome of the Rod there was a hole inade, for to put in a winde, to turne with a barrell, to gather up his Line, and loose at his pleasure; this was his manner of Trouling: But I will pawn my credit, that I will shew a way, either in Maior, Pond, or River, that shall take more Pikes than any Trouler with his Rod: And thus it is. First, take forked stick, a Line of twelve yards long wound upon it, at the upper end, leave about a yard, either to tye a bunch of Sags, or a Blindder, to Boy up the Fish, and to carry it from the ground : the Bait must be a live Fish, either Dace, 
or Gudgin, or Roach, or a small Trout : the forked stick must have a slit in the one side of the fork to put in the Line, that you may set your live Fish to swimme at a gage, that when the Pike taketh the Bait, he may have the full liberty of the Line for his feed.

You may turne these loose, either in Pond or River : in the Pond with the winde all day long, the more the better : at night set some small weight, as may stay the Boy, as a Ship lyeth at Anchor, till the Fish taketh. For the River, you must turn all loose with the streame; two or three be sufficient to shew pleasure, gaged at such a depth as they will go currant downe the River; there is no doubt of sport, if there be Pikes : for the hooks, they must be doubled hooks, the shanks should be somewhat shorter than ordinary: my reason is, the shorter the hook is of the shank, it will hurt the live Fish the lesse, and must be armed with small wyre well softned; but I hold a hook armed with twisted silk to be better, for it will hurt the live fish least.

If you arm your hook with wyre, the neeld must be made with a small hook at the one end thereof. If you arme with silke, the neeld must be made with an eye : then must you take one of those Baits alive (which you can get) and with one of your neelds enter within a strawes breath of the Gill of the Fish, so put the neeld betwixt the skin and the Fish; then pull the neeld out at the hindmost finne, and draw the arming thorow the Fish, until the hook come to lye close to the Fishes bodie: But I hold for those that be armed with wyre to take off the hook, and put the neeld in the hindmost fin and so to come forth at the Gill; then put on the hook drawn close to the body, 'twill hurt the live Fish the less, so knit the arming with the live Fish to the Line; then put off either in Maior or Pond, with the winde, in the River with the stream : The more you put off in Maior or Pond, you are like to have the more pleasure : For the River $I$ have shewed you before.

There is a time when Pikes goe a Frogging Ditches, and in the River to Sun them, as in May, June and July, there is a speedy way to take them, and not to misse scarce one in twenty.

You must take a Line of six or eight foot long, arm a 
large hook, of the largest size that is made ; arm it to your Line, lead the shank of your hook very handsom, that it may be of such a weight as you may guide the hook at your pleasure: you may strike the Pike, you see, with the bare hook where you please: this Line and hook doth far exceed snaring.

The principall sport to take a Pike, is to take a Goose or Gander, or Duck: take one of the Pike Lines I have shewed you before : tye the Line under the left wing, and over the right wing, about the body, as a man weareth his Belt : turne the Goose off into a Pond, where Pikes are, there is no doubt of sport, with great pleasure, betwixt the Goose and the Pike: It is the greatest sport and pleasure that a noble Gentleman in Shropshire doth give his friends entertainment with.

The way to make the best paste is, Take, a reasonable quantity of fresh Butter, as much fresh sheeps Suet, a reasonable quantity of the strongest Cheese you can get, with the soft of an old stale white loafe; beat all this in a Morter till it come to perfect paste; put as much on your hook as a green pease.

There are many wayes to take Eeles : I will shew you a good way to take a dish of Eeles. When you stay a night or two Angling, take four or five Lines, such as be laid for Pikes, of fourteen or fifteen yards long, and at every two yards make a noose, to hang a hook armed either to double thred, or silk twist; for it is better then wyre: Bait your Hooks with Millors-thumbs, Loaches, Menowes, or Gudgins: tye to every noose a Line baited : these Lines must be laid crosse the River in the deepest places, either with stones, or pegged, so the Line lie in the bottome of the river, there is no doubt of taking a dish of Eeles; you must have a small neeld with an eye, to bait your hooks.

Now to shew how to make Flies: learn to make two Flies, and make all : that is, the Palmer ribbed with silver or gold; and the May-flie : these are the ground of all Flies.

We will begin to make the Palmer Flie: You must arme your Line on the inside of the hook; take your Scisers, and cut so much of the brown of the Mallards feather, as in your owne reason shall make the wings, then lay the outmost 
part of the feather next the hook, and the point of the feather towards the shanke of the hook, then whip it three or four times about the hook with the same silk you armed the hook: then make your silk fast: then you must take the hackle of the neck of a Cock or Capon, or a Plovers top, which is the best, take off the one side of the feather, then you must take the hackle silk, or cruell, gold or silver thred; make all these fast at the bent of the hook, then you must begin with Cruell, and Silver, or Gold, and work it up to the wings, every bout shifting your fingers, and making a stop, then the gold will fall right, then make fast : then work up the hackle to the same place, then make the hackle fast : then you must take the hook betwixt your finger and thumb, in the left hand, with a neeld or pin, part the wings in two : then with the arming silk, as you have fastned all hitherto, whip about as it falleth crosse betwixt the wings, then with your thumb you must turne the point of the feather towards the bent of the hook, then work three or four times about the shank, so fasten, then view the proportion.

For the other Flies: If you make the grounds of Hogswooll, sandy, black or white ; or the wooll of a Bear, or of a two year old red Bullock: you must work all these grounds upon a waxed silk, then you must arm and set on the wings, as I have shewed before: For the May-flie, you work the body with some of these grounds, which is very good, ribbed with a black hair ; you may work the body with Cruels, imitating the Colour, or with Silver, with suiting the wings. For the Oak-flie, you must make him with Orange-tauny and black, for the body, and the brown of the Mallards feather for the wings. If you do after my directions, they will kill fish, observing the times fitting, and follow my former Directions.

If any worthy or honest Angler cannot hit of these my Directions, let him come to me, he shall read and I will work, he shall see all things done according to my foresaid Directions : So I conclude for the Flie, having shewed you my true Experiments, with the Rod, I will set all labouring sports aside :

And now I am waiting on my Lord with a great Dish of Trouts, who meeting with company, commanded me to turne Scullion, and dresse a Dinner of the Trouts wee 
had taken : whereupon I gave my Lord thıs Bill of fare, which I did furnish his Table with, according as it was furnished with flesh. Trouts in broth, which is restorative: Trouts broyled, cut and filled with sweet Herbes chopt : 'Trouts calvored hot with Antchovaes sauce: 'Trouts boyled; out of which Kettle I make three Dishes; the one for a Soused Dish, another for a Stewd Dish, the third for a hot Dish : the Sauce is Butter, Vinegar, beaten Cinamon, with the juyce of a Lemmon, beaten very well together, that the Sauce is white and thick, or else it is no Sauce for a great man's Table: Trouts fryed, which must be done, and not put into the Pan, untill the Suet boyle very high, and kept with stirring all the time they are frying, being flowr'd first. 'Trouts stew'd : Trouts close, boyled with the calvored Trouts, all in one Kettle and the same liquor: Trouts butter'd with Egs: Trouts roasted: Trouts baked: these are for the first course, before the Salt.

And these are for the latter course. Trouts calvored cold: Trouts flat cold: Baked Trouts: Trouts inarilled, that will eat perfect and sweet three moneths in the heat of Summer: if I did say, for the whole year about, I would make it good.

For the dressing of four or five of the Dishes, I will shew you how I did perform them.

First, I will shew you for the boyling and calvoring, that serves for hot and cold, for first and latter course.

First, you must draw out the Intrails of the fish, cutting the fish two or three times in the back; lay them in a Tray or Platter, put some Vinegar upon them; you shall see the fish turn sanguine, if they be new, presently : you must put so much water in the Kettle as you thinke will cover them, with a pint of Vinegar, a handfull of Salt, some Rosemary and Thyme and sweet Marjoram tyed in a bunch : then you must make this liquor boyle with a fierce fire made of wood: when the liquor hath boyled very well, put in your fish by one and one, keeping your liquor alwayes boyling, untill you have put all in : having provided a cover for your Kettle, so put on the cover : you must have a paire of Bellowes to blow up the fire with speed, that the liquor may boyle up to the top of the Kettle; so the fierce boiling will make the Fish to calvor: provided, the fish be new 
killed : you may let them boile nigh a quarter of an hour ; when they are cold, you may put them in a Tray or earthen Pan, untill you have occasion to use them: be sure they lie covered.

For your stewed Trouts, you must cut them on the side, as for broiling : there are divers wayes of stewing; the English hath one way, the French hath another way, the Italian hath another way : I may speak this ; for I have been admitted into the Kitchins, to furnish men of most Nations, when they have been in England.

We will begin with the English : He broyleth first upon a Charcoale fire; the first thing that you must have a care of is, when your Grid-iron is hot you must coole it with ruff Suet, then the skin of your Fish will not break, with care of turning them : when they are nigh broyled, take them off the Grid-iron; set on a Chafing-dish of coals in a Stew-pan, or Dish; put in a good quantity of fresh Butter, so much Vinegar as will give the relish, a pennyworth of beaten Cinamon; then put in your broyled fish, and let them stew, about halfe an houre will be sufficient, being turned : adorn your Dish with Sippets, take the fish out of the stew-pan, lay them for the service, be sure to squease a Lemmon on them : I will warrant them good victuall.

The Italian he stewes upon a Chafing. dish of coals, with white Wine, Cloves, and Mace, Nutmegs sliced, a little Ginger: you must understand when this fish is stewed, the same liquor that the fish is stewed in, must be beaten with some Butter and the juyce of a Lemmon, before it is dish'd for the service. The French doe add to this a slicc or two of Bacon.

I will shew you the way to marrionate a Trout or other fish that will keep a quarter of a yeare in Summer, which is the Italians rarest Dish for fresh fish, and will eat perfect and sweet.

You must take out the Intrailes as you doe of other fish, and cut theim a-crosse the sides, as you do to broyle, washed clean, dried with a cloth, lay them upon a Tray or board, sprinkle a little salt on them, and flowre them as to frie them, so take your Frying-pan with so much Suet, when it is melted, as the Fish may lye to the midside in the liquor, 
and so fry them; and every time you turn them, flower them againe, untill you finde the fish fryed sufficient : when you think the fish is fryed, take it out of the Pan, and lay it upon some thing, that the liquor may draine out of it; when the fish is cold, you may reare it an end.

You must have a close Vessell to keep this fish and liquor in, that no winde comes in, according to the quantity you make triall of.

For the Liquor. First, you must take halfe ClaretWine, the other halfe Vinegar, two or three Bay-leaves, so much Saffron as a Nut tyed in a cloth, with some Cloves and large Mace, some Nutmeg sliced; boile all these together very well ; when the liquor is cold, and the fish cold, put the fish and liquor into the close Vessell, with three or four Lemmons sliced among the fish ; make all close that no winde can get into the Vessell ; after eight or ten days you may begin to eat of this fish ; the Sauce must be some of the same liquor, with some of a sliced Lemmon.

\section{To dresse a Pike.}

When the Pike cometh into the Kitchin, kill it ; then take a handfull of Salt, with water, and rub the fish very well to take the slime off, draw out the Intrailes; wash the Pike cleane, put a handfull of Salt in the Pikes Belly; then take so much water, with a pinte of Vinegar: if the Pike be any thing large, you must put in at least three handfull of Salt, with a bunch of Rosemary, Thyme, and sweet Marjorain, and two or three green Onyons; boyle your liquor very well with a high fire made of wood; then put in your Pike, cover your Kettle, with your Bellows keep your Kettle boiling verie high for the space of halfe an houre or thereabouts : a Pike asketh great boiling: for the sauce, it is sweet Butter well beaten with some of the top of the same liquor, with two or three Antchovaes, the skin taken off, and the bones taken out, a little Vinegar, so garnish your Dish: when your Pike is Dished, take the juyce of a Lemmon, and put on the top of the fish: there is no doubt but it is good victuall.

I could set downe as many ways to dress Eeles, as would furnish a Lords Table : but I will relate but one. 
Take off the skinne whole, till you come within two inches of the taile, beginning at the head : take out the Intrailes, wash the Eele cleane, drie it with a cloth, scotch it all along both the sides ; take some Pepper and Salt, mixe them together, rub the Eele well with the Pepper, and Salt; draw the skinne on againe whole ; tye the skinne about the head with a little thred lapped round, broyled on a Charcoale fire, let your Grid-iron be hot, rub your Grid-iron with some ruffe Suet; the skinne will not burne; this is good; but take the skin off, and stew the Eele betwixt two Dishes, on a Chafing-dish of Coals, with sweet Butter, Vinegar, and beaten Cinnamon, they will be better.

The boyling of a Carp is the very same way as I have shewed for the Trout, the scales on : no better Sauce can be made than the Antchovaes Sauce. The high-boyling is the way for all fresh-water Fish: I have served seven times seven years, to see the experiment.

If there be any Gentleman that liveth adjoyning to a River side, where Trouts are; I will shew the way to bring them to feed, that he may see them at his pleasure ; and to bring store to the place. Gather great GardenWormes, the quantity of a pinte, ur a quarte, chop them in pieces, and throw them where you intend to have your pleasure ; with feeding often, there is no doubt of their comming; they will come as Sheep to the Pen : you must begin to feed with peeces of worms, by hand, by one and one, untill you see them eat ; then you may feed with Liver or Lights, so your desire will be effected. And thus I conclude this short Treatise.

\section{F INIS.}


e

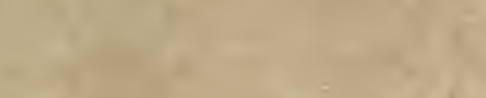

4. non

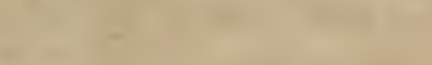

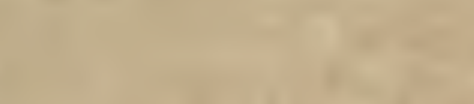

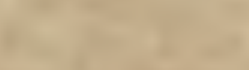

-

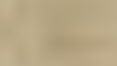

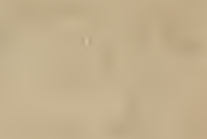

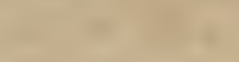

$+$

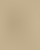

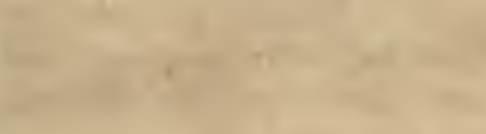

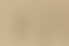

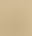




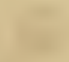

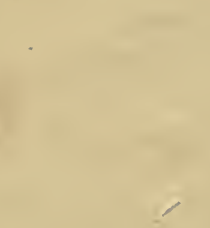

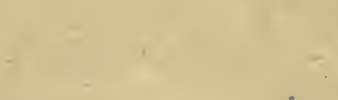

$+2$ 



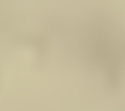

c<smiles>CCC</smiles>
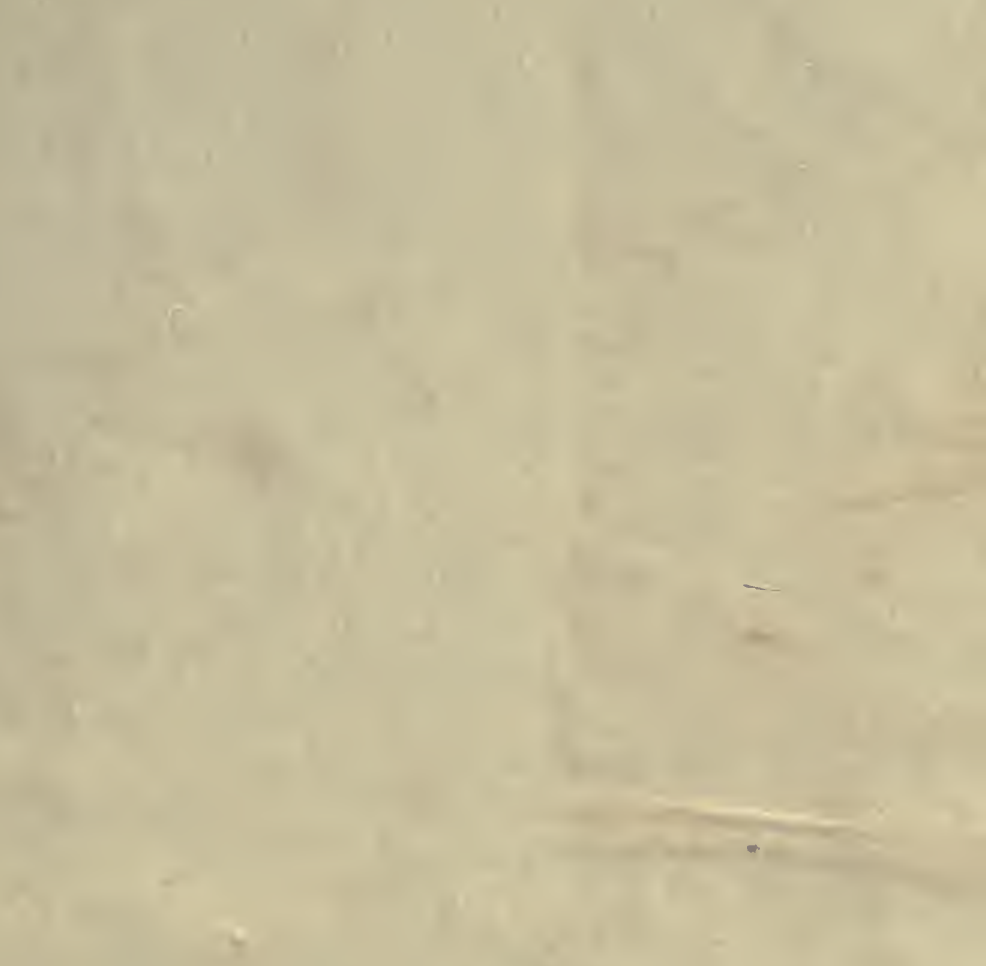
14 DAY USE

RETURN TO DESK FROM WHICH BORROWED

\section{LOAN DEPT.}

This book is due on the last date stamped below, 0 on the date to which renewed.

Renewed books are subject to immediate recall.

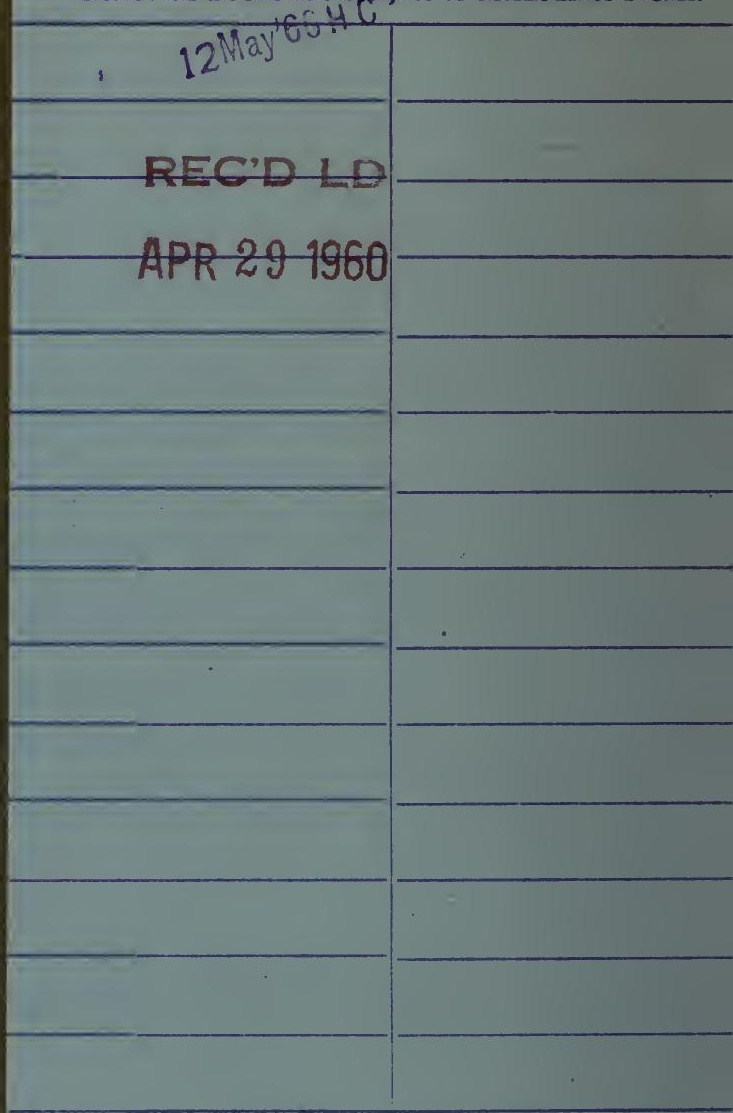


YC $12566^{\prime}$ 
H.

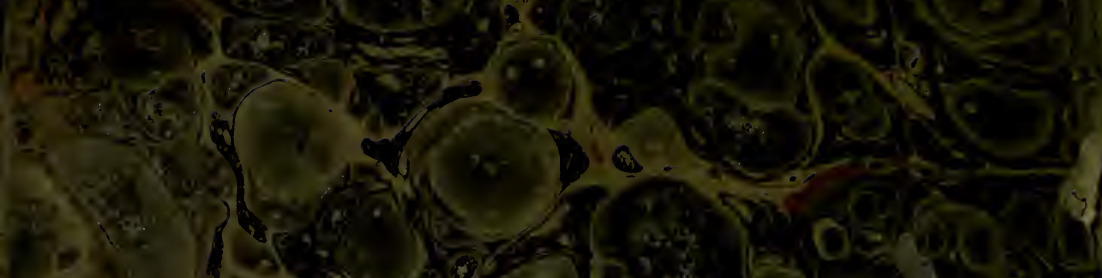

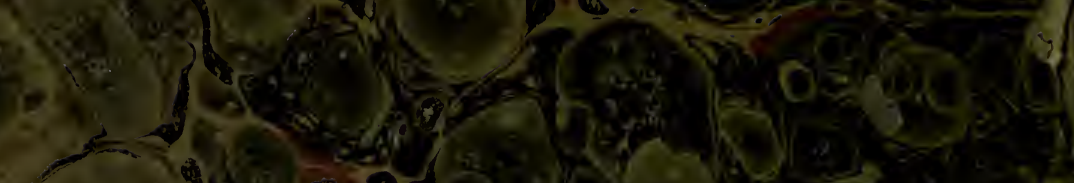

(t)

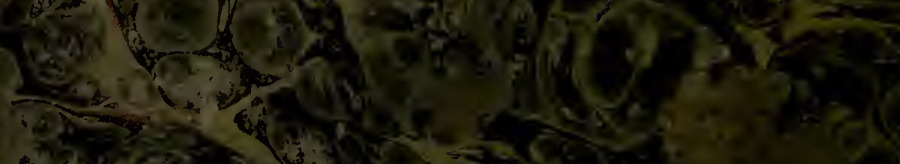

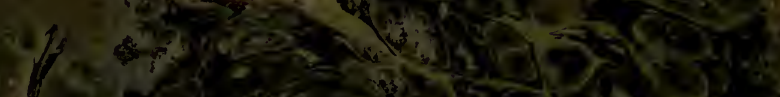

i.

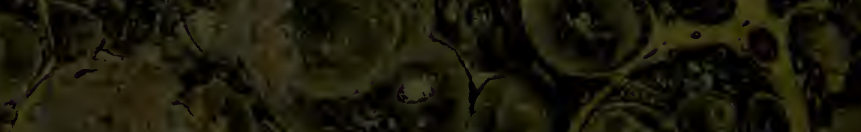

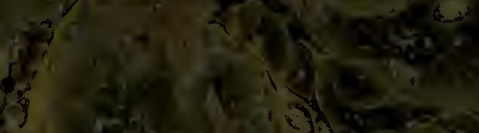

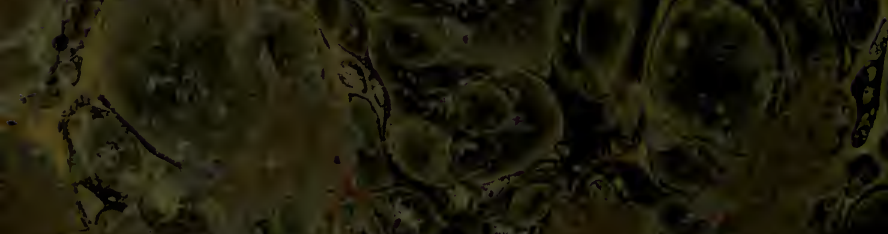

$-\frac{2}{4}$

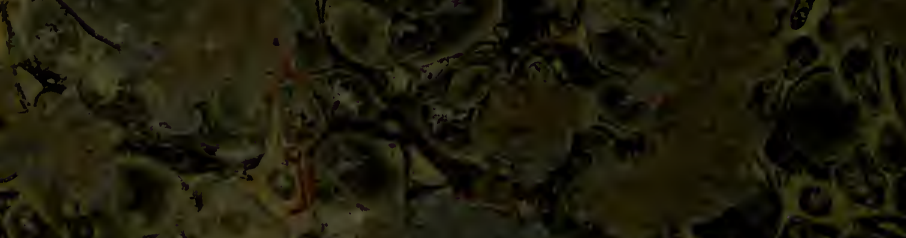

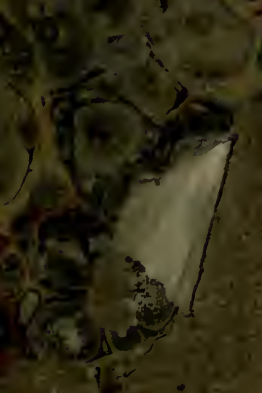

t)

$a^{2} x^{2}+2,-3$

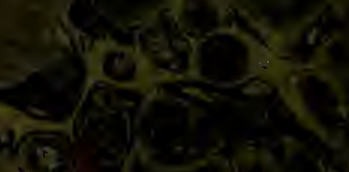

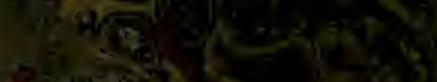

cosesty

$(-2)$
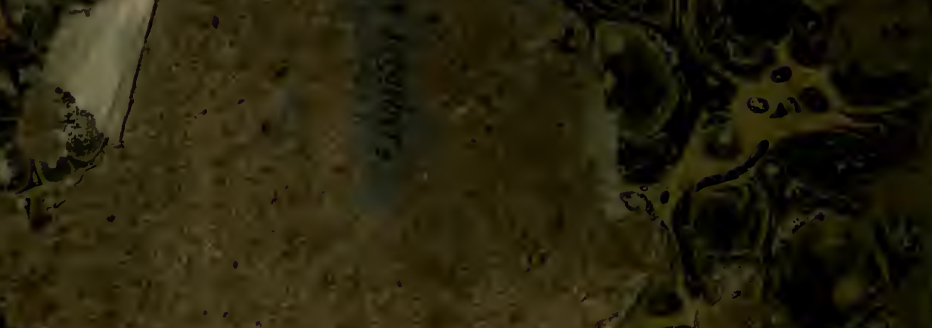

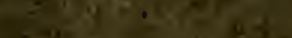

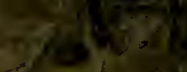

